\title{
Hubungan Hipertirotropinemia Terhadap Tingkat dan Aspek Kecerdasan Anak TK di Desa Seloharjo Kecamatan Pundong, Bantul, Yogyakarta
}

\author{
Indri Hapsari, S. Yudha Patria, IL. Gamayanti \\ Bagian Ilmu Kesehatan Anak Fakultas Kedokteran Universitas Gadjah Mada-RSUP Dr. Sardjito, \\ Yogyakarta
}

Latar belakang. Hipertirotropinemia (peningkatan TSH) menunjukkan adanya insufisiensi saturasi reseptor T3 di otak dan potensial berisiko defisiensi dalam perkembangan kecerdasan. Semakin muda anak mengalami defisiensi hormon tiroid maka semakin berat terhadap gangguan kecerdasan. Hormon tiroid dirangsang sekresinya oleh TSH (Thyroid stimulating hormone). Hipertirotropinemia digunakan sebagai penapis pertama dalam deteksi gangguan tiroid.

Tujuan. Mengetahui adanya hubungan hipertirotropinemia dengan tingkat dan aspek kecerdasan anak taman kanak-kanak (TK) di Desa Seloharjo, Kecamatan Pundong, Bantul, Yogyakarta.

Metode. Rancangan penelitian potong lintang dengan jumlah subjek 51 anak dari dua TK di Desa Seloharjo selama bulan Desember 2010. Desa Seloharjo dipilih karena termasuk daerah endemik GAKI, sumber data lengkap, dan bisa dijangkau. Penilaian dilakukan terhadap kadar tetes darah TSH (dengan ELISA) dan tingkat kecerdasan serta aspek (dengan Stanford-Binet). Analisis dengan uji kai-kuadrat dan uji regresi logistik.

Hasil. Terdapat 39,2\% responden termasuk hipertirotropinemia dengan rerata TSH 5,59 $\mu \mathrm{UI} / \mathrm{mL}$. Intelligency Quotient poin di bawah rata-rata $25,5 \%$ dengan rerata 96,8 poin. Anak hipertirotropinemia dengan IQ di bawah rata-rata 6 orang (30\%) dengan rerata TSH 7,63 $\mu \mathrm{UI} / \mathrm{ml}$ (kenaikan 1,38 kali) dan rerata IQ 81 poin. Tidak didapatkan hubungan bermakna antara kadar TSH dengan tingkat kecerdasan ( $\mathrm{p}=0,553$, $\mathrm{RP}=1,469,95 \% \mathrm{IK} 0,4-5,254)$ dan enam aspek kecerdasan ( $>00,05)$. Hasil uji regresi logistik menunjukkan variabel lain tidak memengaruhi tingkat kecerdasan, sedangkan untuk aspek penalaran aritmatika terbukti dipengaruhi oleh adanya anggota keluarga yang gondok ( $p=0,045$, RP 8,448, IK95\% 1,050-67,977).

Kesimpulan. Hipertirotropinemia tidak terbukti memengaruhi tingkat dan aspek kecerdasan anak TK. Sari Pediatri 2014;15(6):420-6.

Kata kunci: hipertirotropinemia, tingkat dan aspek kecerdasan, anak TK

Alamat korespondensi:

Dr. Suryono Yudha Patria, SpA. Staf Bag. IKA FK UGM/ RSUP. Dr. Sardjito. Jl. Kesehatan No. 1, Yogyakarta. Telp. (274) 587333, (274)

561616. E-mail: suryono_yudha@idai.or.id

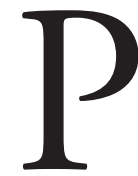

ertumbuhan dan perkembangan anak merupakan hasil interaksi seimbang antara faktor genetik-herediter-konstitusi dan lingkungan. Faktor lingkungan memberikan 
3 kebutuhan dasar anak, yaitu kebutuhan fisikbiomedis (asuh) yang mencakup nutrisi, kebutuhan kasih sayang/emosi (asih), dan kebutuhan bermain/ stimulasi (asah). ${ }^{1}$ Iodium sebagai nutrisi mikro dibutuhkan dalam perkembangan otak dan kecerdasan anak. Defisiensi ringan, bahkan borderline juga mempunyai efek jangka panjang terhadap gangguan perkembangan dan gangguan belajar pada masa depan anak. ${ }^{2}$ Meta-analysis 18 penelitian menunjukkan anak-anak yang tinggal di daerah defisiensi iodium mempunyai intelligence quotion (IQ) 13,5 poin lebih rendah dari pada populasi anak yang setara yang tidak mengalami defisiensi iodium. ${ }^{3}$

Organ tubuh yang bertanggung jawab mengelola iodium adalah kelenjar tiroid. Hormon tiroid salah satunya berefek pada pertumbuhan dan perkembangan sistem saraf pusat dan tulang. ${ }^{4}$ Tiroid diatur oleh hormon perangsang tiroid (TSH=thyroid stimulating hormoneltirotropin), suatu glikoprotein yang dihasilkan dan disekresi oleh hipofisis anterior. Aktivasi kelenjar tiroid diatur melalui mekanisme timbal balik negatif dari thyroid-hypothalamus-pituitary axis. ${ }^{5}$ Kenaikan TSH serum, kecuali pada keadaan patologik yang sangat jarang, menunjukkan adanya insufisiensi saturasi reseptor T3 di otak, tentunya juga kadar hormon tiroid dalam serum. Sehingga peningkatan TSH serum menunjukkan adanya risiko potensial defisiensi dalam perkembangan otak. Serum T3 dan T4 merupakan petunjuk yang kurang spesifik sebagai indikator defisiensi karena kadarnya berubah-ubah dan sangat dipengaruhi oleh usia dan jenis kelamin. ${ }^{6}$ Defisiensi iodium banyak terjadi di daerah endemis GAKI (gangguan akibat kekurangan iodium). Di dunia, angka tertinggi terdapat di negara berkembang (30\%) yang populasi penduduknya tinggal di daerah defisiensi iodium. ${ }^{7}$ Prevalensi total goiter rate (TGR) atau angka pembesaran kelenjar gondok sebagai indikator masalah GAKI di Indonesia pada anak usia sekolah 9,8\% berdasarkan survei terakhir tahun 1995 dan dipublikasikan Depkes di tahun 1998. ${ }^{8}$ Data Abunanin ${ }^{9}$ dari 17 Kecamatan di Bantul, Yogyakarta, terdapat dua kecamatan endemis ringan, satu sedang dan satu berat, yaitu Kecamatan Pundong dengan TGR $\geq 30 \%$.

\section{Metode}

Penelitian bersifat observasional (non eksperimental). Rancangan potong lintang (cross sectional) digunakan untuk menilai hubungan hipertirotropinemia dengan aspek dan tingkat kecerdasan anak TK. Penelitian dilaksanakan Desember 2010 pada anak TK ABA Seltim, Seloharjo dan TK ABA Tunas Harapan Blali, Kecamatan Pundong, Kabupaten Bantul, Yogyakarta. Kriteria inklusi adalah anak TK laki-laki dan perempuan yang lahir di Desa Seloharjo Kecamatan Pundong, dan menyetujui mengikuti penelitian. Kriteria eksklusi adalah anak yang mengonsumsi glukokortikoid ${ }^{10}$ dan terapi suplementasi iodium sejak 14 bulan yang lalu. ${ }^{11}$

Penilaian kecerdasan dilakukan oleh Psikolog dengan menggunakan Stanford Binet Fifth edition, berikutnya anak diambil darahnya dengan bloodlancet, lalu tetes darah diletakkan pada kertas filter untuk diukur kadar TSH dengan metode ELISA. Dikatakan hipertirotropinemia apabila kadar TSH $\geq, 5 \mu \mathrm{UI} /$ ml. ${ }^{12}$

\section{Hasil}

Didapatkan 39,2\% subjek yang termasuk hipertirotropinemia, proporsi perempuan 55\% (11 anak) dan laki- laki 45\% (9 anak). Kadar rerata TSH keseluruhan $5,59 \mu \mathrm{IU} / \mathrm{mL}$, kadar minimum 2,57, dan kadar maksimum 14,24 $\mu \mathrm{UI} / \mathrm{mL}$ (Gambar 1). Prevalensi anak TK yang mengalami hipertirotropinemia cukup tinggi $(39,2 \%)$ menunjukkan anak-anak tersebut tinggal di daerah endemik sedang GAKI.

Tingkat kecerdasan subjek 60,8\% rata-rata (IQ 90109), $17,6 \%$ rata-rata bawah (IQ $80-89), 7,8 \%$ batas lemah (IQ 70-79), 11,75\% rata-rata atas (IQ 110-119), dan 2\% superior (IQ 120-139) (Gambar 2).

Tingkat kecerdasan subjek yang diukur dengan Stanford Binet didapatkan 25,5\% subjek yang memili-

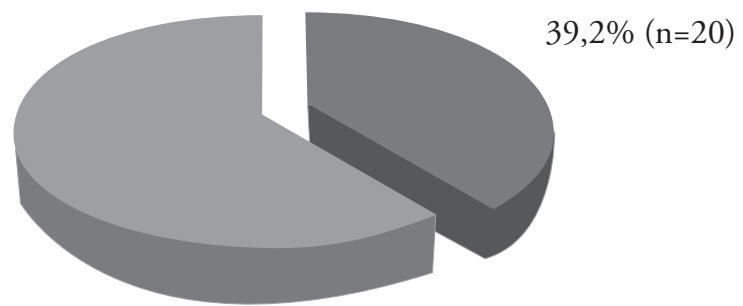

Hipertirotropinemia $(>5,5 \mu \mathrm{UI} / \mathrm{mL})$

Normal $(0,6-5,5 \mu \mathrm{UI} / \mathrm{mL})$

Gambar 1. Prevalensi hipertirotropinemia 


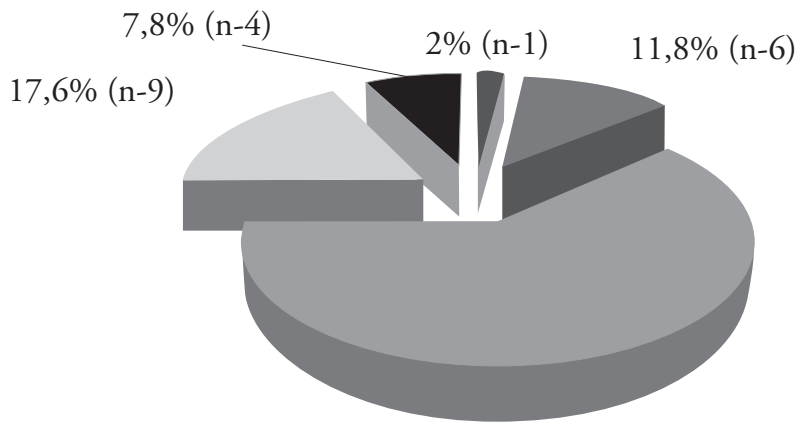

Superior (IQ 120-139)

Rata-rata atas (IQ 110-119)

Rata-rata(IQ 90-109)

Rata-rata bawah (IQ 80-89)

Gambar 2. Prevalensi tingkat kecerdasan

ki IQ poin di bawah rata-rata, sisanya $(74,5 \%)$ memiliki IQ poin rata-rata ke atas. Rerata IQ keseluruhan 96,8, IQ minimum 71 dan IQ maksimum 124 (Tabel 1).

Enam (30\%) anak yang hipertirotropinemia memiliki tingkat kecerdasan di bawah rata-rata, rerata TSH 7,63 $\mu \mathrm{IU} / \mathrm{mL}$ (kenaikan 1,38 kali) dan rerata IQ 81 poin. Tujuh (35\%) anak memiliki tingkat kecerdasan rata-rata, rerata TSH 7,3 $\mu \mathrm{IU} / \mathrm{mL}$ (kenaikan 1,32 kali) dan rerata IQ 100 poin; 4 (20\%) anak memiliki tingkat kecerdasan rata-rata atas dengan rerata TSH 7,37 $\mu \mathrm{IU} / \mathrm{mL}$ (kenaikan 1,34 kali) dan rerata IQ 115 poin; dan $1(20 \%)$ anak memiliki tingkat kecerdasan

Tabel 1. Prevalensi tingkat kecerdasan

\begin{tabular}{lc}
\hline Tingkat kecerdasan & $(\mathrm{n}=51, \%)$ \\
\hline Rata-rata ke atas (IQ 90-139) (n=38, \%) & \\
$\quad$ Superior (IQ 120-139) & $1(2)$ \\
Rata-rata atas (IQ 110-119) & $6(11,75)$ \\
Rata-rata (IQ 90-109) & $31(60,75)$ \\
Di bawah rata-rata (IQ < 90) (n=13, \%) & \\
$\quad$ Rata-rata bawah (IQ 80-89) & $9(17,6)$ \\
Batas lemah (IQ 70-79) & $4(7,8)$ \\
\hline
\end{tabular}

superior, kadar TSH 14,24 $\mu \mathrm{IU} / \mathrm{mL}$ (kenaikan 2,58 kali) dan IQ 124 poin (Tabel 2).

Aspek kecerdasan 20 anak hipertirotropinemia yaitu untuk aspek pengetahuan umum 12 (60\%) mendominasi memiliki skor kurang, sama halnya dengan aspek ingatan dan konsentrasi $(n=10)$ dan aspek penilaian penalaran $(\mathrm{n}=10)$. Hanya 11 anak (55\%) memiliki dominan skor baik pada aspek kemampuan visual-motorik dan penalaran aritmatika $(\mathrm{n}=12)$. Sedangkan $6(30 \%)$ anak belum bisa dinilai kemampuan penalaran aritmatikanya karena umur kronologis anak kurang dari 6 tahun dan belum mampu mengerjakan tes di atas umur mentalnya Gambar 3.

Didapatkan $30 \%$ anak dengan hipertirotropinemia yang mempunyai tingkat kecerdasan di bawah ratarata, RP 1,469 (IK95\%: 0,4-5,254) yang artinya anak dengan hipertirotropinemia berisiko 1,5 kali mempunyai tingkat kecerdasan di bawah rata-rata (IQ yang tergolong rata-rata bawah dan batas lemah) dibandingkan anak tanpa hipertirotropinemia, meskipun tidak bermakna secara statistik $(\mathrm{p}=0,553)$ (Tabel 3).

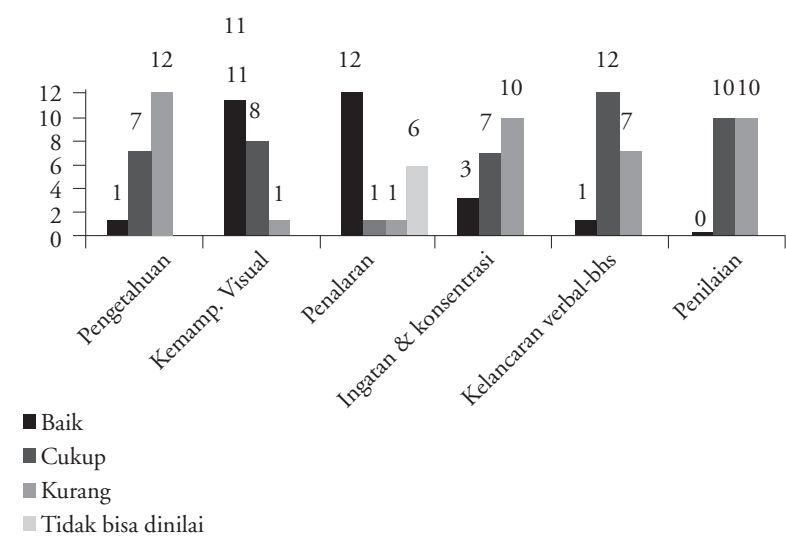

Gambar 3. Proporsi aspek kecerdasan anak yang hipertirotropinemia $(\mathrm{n}=20)$

Tabel 2. Prevalensi tingkat kecerdasan anak yang hipertirotropinemia

\begin{tabular}{lccc}
\hline Tingkat kecerdasan & $(\mathrm{n}=20, \%)$ & Rerata TSH $($ besarnya kenaikan) & Rerata IQ \\
\hline Di bawah rata-rata (IQ <90) & $6(30)$ & $7,63 \mu \mathrm{IU} / \mathrm{mL}(1,38$ kali) & 81 \\
Rata-rata (IQ 90-109) & $9(45)$ & $7,13 \mu \mathrm{IU} / \mathrm{mL}(1,29$ kali) & 100 \\
Rata-rata atas (IQ 110-119) & $4(20)$ & $7,37 \mu \mathrm{IU} / \mathrm{mL}(1,34$ kali) & 115 \\
Superior (IQ >120) & $1(5)$ & $14,24 \mu \mathrm{IU} / \mathrm{mL}(2,58$ kali) & 124 \\
\hline
\end{tabular}


Indri Hapsari dkk: Hubungan hipertirotropinemia terhadap tingkat dan aspek kecerdasan anak TK

Tabel 3. Hubungan hipertirotropinemia dengan tingkat kecerdasan

\begin{tabular}{|c|c|c|c|c|c|}
\hline \multirow[b]{2}{*}{ Variabel } & \multicolumn{2}{|c|}{ Tingkat kecerdasan } & \multirow[b]{2}{*}{$\mathrm{p}$} & \multirow[b]{2}{*}{$\mathrm{RP}$} & \multirow[b]{2}{*}{ IK95\% } \\
\hline & $\begin{array}{r}\text { Di bawah } \\
\text { rata-rata }\end{array}$ & $\begin{array}{c}\text { Rata-rata } \\
\text { ke atas }\end{array}$ & & & \\
\hline \multicolumn{6}{|c|}{ Hipertirotropinemia } \\
\hline Ya & $6(30 \%)$ & $14(70 \%)$ & 0,553 & 1,469 & $0 \quad 0,4-5,254$ \\
\hline Tidak & $7(22,5 \%)$ & $24(77,5 \%)$ & & & \\
\hline
\end{tabular}

Masing-masing aspek kecerdasan apabila dihubungkan dengan kadar TSH dengan hipertirotropinemia memiliki $100 \%(\mathrm{n}=20)$ defek aspek pengetahuan umum dengan $\mathrm{RP}=1,107$ (IK95\%:0,987-1,242). Hal tersebut berarti hipertirotropinemia tidak menyebabkan defek aspek pengetahuan umum dari kecerdasan yang dimiliki anak dibandingkan anak normal $(\mathrm{p}=0,271)$. Untuk aspek kemampuan visual motorik juga tidak memiliki risiko defek dibandingkan anak normal ( $\mathrm{RP}=1,007$, IK95\%:0,325-3,115, p=0,991). Aspek ingatan dan konsentrasi mempunyai risiko terkena defek 2,6 kali dibandingkan anak normal $(\mathrm{RP}=2,559$, IK95\%:0,388-16,88, p=0,369). Sedangkan untuk kemampuan aritmatika mempunyai efek protektif bagi defek 0,23 kali dibandingkan anak normal (IK95\%: 0,045-1,207, $\mathrm{p}=0,065)$.

\section{Pembahasan}

Penelitian kami membuktikan bahwa daerah yang dahulu termasuk endemik berat selama 14 tahun telah berhasil melakukan berbagai intervensi, meskipun belum pernah dilakukan evaluasi terhadap status tiroid masyarakatnya. Dalam studi epidemiologi GAKI, pemeriksaan TSH memberikan informasi kondisi faal tiroid di populasi untuk jangka waktu yang lama dan berkorelasi baik dengan kadar eskresi iodium dalam urin (UIE) ${ }^{13}$ meskipun tidak rutin direkomendasikan untuk skrining karena mahal, tidak simpel, dan invasif. Namun, kesulitan ini harus menjadi catatan karena tujuan akhir koreksi defisiensi iodium tidak hanya jumlah populasi yang mengonsumsi garam beryodium dan kadar iodium yang normal dalam urin. Terpenting adalah kembali normalnya faal tiroid yang ditunjukkan dengan pemeriksaan biokimiawi, baik hormon tiroid maupun TSH. ${ }^{6}$ Penelitian di empat negara ditunjukkan indikator lain selain kadar TSH yang dapat digunakan untuk mengetahui status tiroid dan kondisi defisiensi iodium di populasi; antara lain (1) kadar eskresi iodium dalam urin (UIE) yang menjadi indikator terbaik status intake iodin terkini/saat pemeriksaan; (2) TGR dengan palpasi dan USG tiroid merepresentasikan defisiensi iodium kronik dan dapat sebagai indikator apabila intake iodium di masyarakat telah stabil selama $\geq 2$ tahun, tetapi terbukti kurang bermanfaat sebagai indikator apabila di masyarakat sudah dilakukan intervensi pengobatan; (3) pengukuran Tg terbukti kurang bermakna sebagai indikator status iodium dibandingkan kedua indikator di atas. ${ }^{13}$

Pembahasan utama dalam psikologi adalah bahwa tes intelegensi seringkali bias budaya, yaitu lebih menguntungkan anak perkotaan daripada pedesaan, kelas menengah daripada kelas bawah, dan kulit putih daripada kulit hitam. ${ }^{14}$ Begitu juga penelitian kami, sangat dimungkinkan terjadi bias budaya untuk penilaian kecerdasan, ditambah lagi apabila tester tidak begitu mahir dalam menggunakan bahasa subjek (bahasa Jawa). Psikolog (tester) seringkali harus menjelaskan perintah tes berulangkali karena kemampuan bahasa subjek belum sepenuhnya mengerti bahasa Indonesia dan testerpun tidak banyak memahami kosakata bahasa Jawa. Padahal, aturan tes ini tidak diperbolehkan mengulang perintah karena salah satu penilaian tes adalah menilai konsentrasi dan kecepatan dalam memahami perintah. ${ }^{15}$

Hipotesis penelitian kami tidak terbukti, kemungkinan disebabkan oleh faktor internal lain, seperti derajat beratnya yang ditunjukkan dengan besarnya kenaikan kadar TSH dan kondisi hipertirotropinemia yang lama, faktor genetik maupun faktor eksternal berupa status iodium, status gizi, motivasi, dan intensitas belajar yang tidak diteliti. Status iodium dinilai untuk mengukur asupan iodium 24 jam sebelum pemeriksaan dengan cara pengukuran ekskresi iodium urin (EIU). Selain itu, status iodium juga dapat diukur dengan palpasi ataupun USG tiroid untuk menilai asupan iodium jangka panjang. Faktor lain yang kemungkinan menyebabkan hipotesis tidak terbukti adalah persentase subjek yang tidak 
hipertirotropinemia dengan IQ di bawah rata-rata mendekati persentase anak yang hipertirotropinemia dengan IQ di bawah rata-rata $(22,5 \%$ vs $30 \%)$. Begitu juga anak yang hipertirotopinemia dengan IQ tidak di bawah rata-rata/rata-rata ke atas (positif palsu) lebih banyak daripada IQ di bawah rata-rata dengan hipertirotropinemia (70\% vs 30\%). Laporan kasus yang membandingkan 11 anak subklinis hipotiroid/ hipertirotropinemia usia 3,6-12,6 tahun dengan riwayat hipotiroid kongenital dan hipotiroid didapat (terdiagnosis $>1$ tahun) dan telah diterapi $L$-thyroxin memiliki rerata kadar TSH $8,2 \mu \mathrm{IU} / \mathrm{mL}$ terbukti tidak memengaruhi kemampuan verbal dan kordinasi visual-motorik, tetapi mempunyai risiko menyebabkan gangguan perilaku seperti GPP/H. ${ }^{16}$

Subjek yang tidak memiliki riwayat hipotiroid kongenital dan rerata kenaikan kadar TSH 7,63 $\mu \mathrm{IU} / \mathrm{mL}$ (1,38 kali TSH normal). Namun, kenaikan sedikit saja dari TSH (1,76 kali) rerata 3,0 $2,3 \mu \mathrm{UI} /$ $\mathrm{mL}$ pada anak hipotiroid (ditunjukkan dengan kadar T4 $\leq 45 \mathrm{nmol} / \mathrm{L}$ ) memengaruhi defek terhadap kecerdasan (skor kelancaran membaca, aritmatika, dan belajar (the French learning task)) dibandingkan dengan anak eutiroid. ${ }^{17}$ Peningkatan kadar TSH 1,76 kali sudah mampu menyebabkan defek pada kecerdasan anak sehingga dibutuhkan langkah pencegahan, baik dengan penggalakkan konsumsi garam beryodium sesuai standar maupun pemeriksaan lanjutan (pengukuran TSH berseri dan T4) sebagai konfirmasi. ${ }^{11}$ Iodium dibutuhkan dalam sintesis hormon tiroid, T3 akan berikatan dengan reseptor nukleus (TR $\alpha 1$, TR $\beta 1$, dan TR $\beta 2$ ). Reseptor nukleus ini mengatur ekspresi dari berbagai tempat yang spesifik dalam otak termasuk mengatur kecepatan dan urutan perkembangan sel otak (sel neuron dan sel glia). ${ }^{18}$

Terdapat 35\% anak yang hipertirotropinemia, tetapi memiliki tingkat kecerdasan rata-rata (IQ 90109) dengan rerata TSH $7,3 \mu \mathrm{IU} / \mathrm{mL}$ (kenaikan 1,32 kali), dan 20\% memiliki tingkat kecerdasan rata-rata atas (IQ 110-119) dengan rerata TSH 7,37 $\mu \mathrm{IU} /$ $\mathrm{mL}$ (kenaikan 1,34 kali), serta 5\% memiliki tingkat kecerdasan superior dengan rerata TSH 14,24 $\mu \mathrm{IU} / \mathrm{mL}$ (kenaikan 2,58 kali). Hasil tersebut hampir sama dengan penelitian Wu dkk ${ }^{19}$ yang menunjukkan anak dengan kadar TSH yang tinggi memiliki performance kognitif yang lebih baik daripada anak dengan TSH rendah dan normal. Apabila dibandingkan aspek kecerdasan yang berupa ingatan dan konsentrasi, terlihat anak dengan hipertirotropinemia dan IQ di bawah rata-rata memilki kemampuan lebih rendah (skor 0,31=kurang) dibandingkan dengan anak dengan hipertirotropinemia yang memiliki tingkat kecerdasan rata-rata. Gangguan kognitif dan perilaku, termasuk gangguan konsentrasi dan pemusatan perhatian disebabkan kadar TSH yang rendah. ${ }^{20}$ Aspek kemampuan verbal dan bahasa tidak diperoleh nilai secara statistik disebabkan anak yang hipertirotropinemia $100 \%$ mengalami defek/skor kurang dan cukup dan yang tidak hipertirotropinemia juga 100\% mengalami defek/skor kurang dan cukup. Hal tersebut mungkin saja sudah menunjukkan adanya defek akibat defisiensi iodium yang terjadi di komunitas, meskipun subjek tidak didapatkan adanya hipotiroid kongenital. Sebab, iodium pada usia di atas 3 tahun berfungsi lebih kepada pembentukkan sel neuron baru untuk mengganti sel yang mati, pertumbuhan dan perkembangan sel glia serta proses mielinisasi.

Hasil analisis multivariat menunjukkan adanya variabel lain yang memengaruhi tingkat kecerdasan yaitu umur kurang dari 6 tahun. Hal tersebut menunjukkan bahwa umur kurang dari 6 tahun mempunyai risiko penurunan tingkat kecerdasan 3,7 kali dibandingkan umur yang lebih tua, meskipun rentang kepercayaan yang lebar karena jumlah sampel yang tidak terlalu banyak. Kondisi ini perlu digali data lebih jauh apakah selama umur 6 tahun kebelakang ada kejadian khusus yang memengaruhi kecerdasan anak, misalnya bencana alam gempa bumi di tahun 2006 yang mengakibatkan goncangan psikis maupun fisik. Aspek kecerdasan dipengaruhi oleh variabel yang berbeda, tetapi yang bermakna secara statistik hanyalah aspek kemampuan penalaran aritmatika. Kualitas pola pengasuhan dan lingkungan sosial anak yang rendah memiliki risiko 3,85 kali menurunkan kemampuan visual motorik dibandingkan anak yang mempunyai skor HOME lebih tinggi. Hal serupa juga ditunjukkan penelitian Huda dkk, ${ }^{17}$ anak dengan stimulasi lingkungan rumah yang rendah berupa ketersediaan alat main (material) maupun stimulasi aktivitas fisik yang kurang mempengaruhi kecerdasan anak. Anak yang terbiasa dengan stimulasi edukasi yang baik, berarti kebutuhan dasar asah terpenuhi. Mereka akan memiliki banyak kesempatan belajar dan menyimpan memori untuk bekal kehidupannya kelak.

Kemampuan penalaran aritmatika dipengaruhi oleh riwayat/turunan gondok dari keluarga baik ibu maupun nenek 8,4 kali menurunkan kemampuan terhadap aspek kecerdasan. Hal tersebut serupa dengan penelitian Rapa dkk, ${ }^{21}$ anak dengan riwayat keluarga 
penyakit tiroid memiliki risiko 1,9 kali dibandingkan anak yang anggota keluarganya normal, kemungkinan karena adanya mutasi nonsinonim dari gen TSH-R, bahkan satu anak telah terdeteksi letak mutasi pada posisi 1559 pada exon 10 (W520X).

\section{Kesimpulan}

Terdapat hubungan antara hipertirotropinemia dengan tingkat dan aspek kecerdasan anak TK di TKABA Seltim dan TK Blali Desa Seloharjo Kecamatan Pundong, Bantul, Yogyakarta. Prevalensi hipertirotropinemia anak di 2 TK tersebut cukup tinggi dan rerata tingkat kecerdasan adalah rata-rata (IQ 90-109). Aspek kecerdasan terbanyak mengalami gangguan adalah kemampuan ingatan dan konsentrasi serta kelancaran verbal dan bahasa. Kualitas pola pengasuhan dan lingkungan sosial anak memengaruhi aspek kemampuan visual-motorik dan adanya turunan gondok dari keluarga mempengaruhi aspek kemampuan penalaran aritmatika anak TK Desa Seloharjo.

\section{Daftar pustaka}

1. Tanuwidjaya S. Kebutuhan dasar tumbuh kembang anak. Dalam: Narendra MB, Sularyo TS, Soetjiningsih, Suyitno H, Ranuh GI, Wiradisuria S, penyunting. Buku ajar tumbuh kembang anak dan remaja. Edisi ke1. Ikatan Dokter Anak Indonesia. Jakarta: PT. Sagung Seto;2005.

2. Glinoer D. The regulation of thyroid function during normal pregnancy: importance of the iodine nutrition status. Best practice and Research. J Clin Endocrin Metab 2004;18:133-52.

3. Kratzsch J, Pulzer F. Thyroid gland development and defects. Best practices \& research. J Clin Endocrin Metab 2008;22:57-75.

4. Brown RS, Huang S. Thyroid hormones. Dalam: Clinical pediatrics endocrinology. Edisi ke-5. United Kingdom: Blackwell Publishing;2005.

5. Behrman RE, Vaughan VC. Thyroid hormones disorders. Dalam: Nelson: Textbook of Pediatrics. Edisi ke-13. Philadelphia:WB Saunders; 1990.

6. Susanto R. Permasalahan gondok endemik pada anak, dulu, kini dan akan datang. Makalah dipublikasikan memperingati 50 tahun IDAI "Untuk Mereka Kita Bekerja”. Semarang: Bagian IKA RS Kariadi-FK UNDIP; 2006.h.1-13.

7. Anderson M. Takkouche B. Egli I. Allen HE. de Benoist B. Current global iodine status and progress over the last decade towards the elimination of iodine deficiency. Bull World Health Organ 2005;84:518-25.

8. Departemen Kesehatan. Peningkatan konsumsi garam beryodium. Pusat Promosi Kesehatan Depkes RI. Jakarta, 2003.

9. Abunanin DB. Survei pemetaan gangguan akibat kekurangan iodium (GAKI) di DIY, Yogyakarta, Dinas Kesehatan Provinsi DIY, 1996.

10. Surks MI. Rubens S. Drugs and thyroid function. N Engl J Med 1995;333: 1688-94.

11. Zimmermann MB. Conolly BM. Bridson J. Rohner F. Grimci L. Iodine supplementation improves cognition in iodine-deficient school children in Albania : a randomized, controlled, double-blind study. Am J Clin Nutr 2006; 83:108-14.

12. Mac GMH. Congenital hypothyroidism. Dalam: Pescovitz $\mathrm{OH}$. Eugster EA, penyunting. Pediatric endocrinology: mechanisms, manifestations, and management. USA: Lippincot Williams \& Wilkins;2004.

13. Sullivan KM. Shahriari A. Houston R. May W. Mendoza I. Salamatullah Q. Solomons NW. Comparison of different indicators of iodine deficiency in school children. Int J Endocrinol Metab 2005;1:1-9.

14. Mutazalimah. Asyanti. Status yodium dan fungsi kognitif anak sekolah dasar di SDN Kiyaran I Kecamatan Cangkringan Kabupaten Sleman. J Pen Sains \& Teknologi 2009; 10:50-60.

15. Flushberg HT. Skwerer DP. Assesment of intelligence. Dalam: Carey WB. Crocker AC. Coleman WA. Elias ER. Feldman H, penyunting. Developmental-behavioral pediatric. Edisi ke-4. USA: Saunders Elsevier;2009.

16. Aijaz NJ. Flaherty EM. Preston T. Bracken S. Lane AH. and Wilson TA. Neurocognitive function in children with compensated hypothyroidism : lack of short term effects on or off thyroxin. BMC Endocrine Disorders 2006;2:1472-9.

17. Huda SN. Grantham, Rahman KM. Tomkins A. Biochemical hypothyroidism secondary to iodine deficiency is associated with poor school achievement and cognition in Bangladesh children. J Nutr 1999;129:9807.

18. Sethi V. Kapil U. Iodine deficiency and development of brain. Indian J Pediat 2004;71:325-29.

19. Wu T. Flowers JW. Tudiver F. Wilson JL. Punyasavatsut N. Subclinical thyroid disorders and cognitive performance among adolescents in the United States. BMC Pediatr 
Indri Hapsari dkk: Hubungan hipertirotropinemia terhadap tingkat dan aspek kecerdasan anak TK

2006;6:1-6.

20. Alvarez MA. Gomex A. Alavez E. Navarro D. Attention disturbance in Graves' disease. Psychoneuroendocrinology 1983;8:451-4.
21. Rapa A. Monzani A. Moia S. Vivenza SB. Subclinical hypothyroidism in children and adolescence : A wide range of clinical, biochemical, and genetic factors involved. J Clin Endocrin Metab 2009;94:2414-20. 